2017-10

Fishway passage success for migratory rainbow smelt Osmerus mordax is not dictated by behavioural type

\title{
Landsman, SJ
}

http://hdl.handle.net/10026.1/11416

\subsection{2/rra.3176}

River Research and Applications

Wiley

All content in PEARL is protected by copyright law. Author manuscripts are made available in accordance with publisher policies. Please cite only the published version using the details provided on the item record or document. In the absence of an open licence (e.g. Creative Commons), permissions for further reuse of content should be sought from the publisher or author. 


\title{
Fishway passage success for migratory rainbow smelt Osmerus mordax is not dictated by behavioural type
}

\author{
S. J. Landsman ${ }^{1}$ (i) | A. D. M. Wilson²,3 | S. J. Cooke $^{2}$ | M. R. van den Heuvel ${ }^{1}$
}

${ }^{1}$ Canadian Rivers Institute, University of Prince Edward Island, Charlottetown, PE, Canada

${ }^{2}$ Fish Ecology and Conservation Physiology Laboratory, Carleton University, Ottawa, ON, Canada

${ }^{3}$ School of Life and Environmental Sciences, University of Sydney, Sydney, NSW, Australia

\section{Correspondence}

S. J. Landsman, Canadian Rivers Institute, University of Prince Edward Island,

Charlottetown, PE, Canada.

Email: landsman.sean@gmail.com

Funding information

Ducks Unlimited Canada; Prince Edward Island Wildlife Conservation Fund; Natural Sciences and Engineering Research Council of Canada (NSERC), and Irving Oil; Canada Research Chairs Program

\begin{abstract}
Recent research has demonstrated that an individual's behavioural decisions can have a profound impact on an animal's fitness. For anadromous fishes requiring access to spawning habitat above obstructions, successful passage at fishways may at least in part be a function of an individual's behavioural type. The objectives of this study were to determine whether distinct behavioural types-bold and shy-could be distinguished within a population of anadromous rainbow smelt (Osmerus mordax) and, if so, whether passage success at a nature-like fishway varied relative to behavioural type. Field-caught rainbow smelt were tested for individual differences in boldness (i.e., willingness to engage in risk-taking behaviour) using the metrics of exploratory behaviour, general activity, and response to a simulated predator. After testing, 276 rainbow smelt were implanted with a passive integrated transponder tag, released below the fishway, and their movements monitored via a stationary antenna array. The results of our behavioural assays indicated the presence of a behavioural syndrome among rainbow smelt, and that behaviour was partially repeatable. In total, $41.7 \%$ of fish entering the fishway passed successfully, but contrary to our initial prediction, boldness was not a significant predictor of successful passage. Instead, increasing water temperature and decreasing river discharge were consistent predictors of successful passage and greater distances moved through the fishway. Our findings indicate that the nature-like fishway did not select for a particular behavioural type and that individuals representing the spectrum of bold-shy behavioural types could pass.
\end{abstract}

\section{KEYWORDS}

behaviour, boldness, fishway, personality, rainbow smelt, temperament

\section{1 | INTRODUCTION}

The success or failure of fishes to ascend fishways is affected by a variety of factors such as fishway characteristics (Bunt, Castro-Santos, \& Haro, 2012; Clay, 1995; Parasiewicz, Eberstaller, Weiss, \& Schmutz, 1998) and flow patterns within fishways (Bretón, Baki, Link, Zhu, \& Rajaratnam, 2013; Haro, Odeh, Castro-Santos, \& Noreika, 1999; Larinier, 2002a). Success may also be affected by biological factors including physiological condition (Cooke \& Hinch, 2013; Hinch, Cooke, Healey, \& Farrell, 2005; Volpato, Barreto, Marcondes, Andrade Moreira, \& de Barros Ferreira, 2009), swimming capacity (Hinch \& Bratty, 2000; Larinier, 2002b), migratory tendency (Bunt et al., 2012), and migratory motivation (Castro-Santos, 2002). Typically, it is assumed that all fish attempting to pass fishways while en route to spawning grounds will only be constrained by their swimming performance and the flow characteristics within the fishway (Hirsch et al.,
2016). However, behavioural types of individuals within a population of migratory fish could potentially impact successful passage.

Among-individual behavioural differences have been associated with discrete personalities or behavioural types within populations of fishes (Conrad, Weinersmith, Brodin, Saltz, \& Sih, 2011). By testing various behavioural metrics across multiple contexts, researchers have been able to identify "behavioural syndromes" suggestive of distinct personality traits (Sih, Bell, \& Johnson, 2004; Toms, Echevarria, \& Jouandot, 2010). These syndromes can be divided into axes of behaviour, the most common of which is the boldness-shyness axis (Conrad et al., 2011). Boldness has been associated in fishes with greater periods spent actively swimming (Wilson \& Godin, 2010), increased aerobic scope (Binder et al., 2016), more active shoals (Harcourt, Sweetman, Johnstone, \& Manica, 2009), greater risk-taking behaviour in high-predation environments (young fish only, Magnhagen \& Borcherding, 2008; Kortet, Sirkka, Lai, Vainikka, \& Kekäläinen, 2015), 
and lower fecundity (Wilson, Godin, \& Ward, 2010). Similarly, in a migratory context, Chapman et al. (2011) demonstrated that bolder roach (Rutilus rutilus) were more likely to migrate than shyer individuals.

If bold individuals are more active and more exploratory of novel structures, then they may be more motivated to ascend fishways. What little evidence exists relative to boldness and propensity to migrate may support this (Chapman et al., 2011; Rasmussen \& Belk, 2012; Nilsson, 2015; Hirsch et al., 2016). Recent research also demonstrates that improved aerobic scope is linked to bolder individuals of a non-migratory species (juvenile bluegill sunfish Lepomis macrochirus; Binder et al., 2016), but if the same pattern exists for migratory fishes, then it is reasonable to predict that bolder fish might ascend fishways more frequently. Yet fishways themselves can act as artificial selection pressures by favouring individuals with traits better suited to environments containing dams and fish passage structures (McLaughlin et al., 2013). For example, fish found exiting fishways might be larger in size (e.g., Mallen-Cooper \& Stuart, 2007; Maynard, Kinnison, \& Zydlewski, 2017; Volpato et al., 2009), but it is unclear whether fishways select for particular behavioural phenotypes. Ideally, fishways should enable the passage of a wide variety of phenotypes.

In northeastern North America, anadromous rainbow smelt (Osmerus mordax) are a small-bodied fish commonly found in coastal locations (Scott \& Scott, 1988). Rainbow smelt begin spawning shortly after ice-out and prefer riffle-type habitat near the head of tide (Chase, 2006; Scott \& Scott, 1988). Historically, rainbow smelt were considered unable to ascend fishways (Landsman \& van den Heuvel, in press; Moring, 2005), but recent evidence suggests that passage does occur, though passage estimates have yet to exceed $50 \%$ (Clément, Torterotot, \& Bergeron, 2012; Landsman \& van den Heuvel, in press). Developing a better understanding of why rainbow smelt may not be able to pass fishways would be useful to practitioners looking to enhance passage.

The first objective of this study was to determine whether a boldshy behavioural syndrome could be distinguished within a population of anadromous rainbow smelt. To accomplish this, individual rainbow smelt were subjected to three behavioural tests designed to assess exploratory behaviour, activity, and predator avoidance in the field. The second objective was to test the association among behavioural metrics with the upstream movement of telemetered individuals within a nature-like rock-ramp fishway. Movement patterns of interest included passage success and the maximum distance moved within the fishway. We predicted that bolder individuals would move a greater distance in the fishway and be more likely to successfully pass.

\section{2 | METHODS}

\section{1 | Study site and field collections}

Rainbow smelt $\left(n_{\text {total }}=326\right.$ ) were captured using dip nets (net hoop width $20.3 \mathrm{~cm}$, bag depth $45.7 \mathrm{~cm}$, and 0.32-cm mesh) during their spawning migration in the Pisquid River, Prince Edward Island, Canada. Fish capture took place between May 15 and June 5, 2015. Rainbow smelt were sourced from below a nature-like fishway (length: $54.4 \mathrm{~m}$ slope $=2.2 \%$, approximate mean width $7.6 \mathrm{~m}$ ) located approximately 800-m upstream of the head of tide (Figure 1; see also Supporting Information). An Onset (Bourne, Massachusetts) HOBO Water Temperature Logger was installed downstream of the fishway to record hourly water temperatures (resolution $0.1^{\circ} \mathrm{C}$ ). Discharge measurements were taken over a broad range of water levels and regressed against mean daily water level at a nearby gauged river system. The results of our regression analyses indicated a high correlation $(r=.88)$ between our discharge measurements and the gauged water levels.

\section{2 | Experimental tanks}

Behavioural tests were conducted in situ to reduce the likelihood that transportation to and confinement in a laboratory would affect behaviour or adversely impact migratory factors (Wilson, Coleman, Clark, \& Biederman, 1993). Following capture, fish were immediately placed into small refuge chambers inside larger 189-L holding tanks (Rubbermaid Roughneck Jumbo Storage Tote; Figure 2; see also Supporting Information). Affixed to the bottom of each tank were six lines of white electrical tape spaced equidistant apart. The tanks were located within $15 \mathrm{~m}$ of the water's edge.

\section{3 | Objective 1-behavioural trials}

Individuals were placed into the refuge chambers following capture from the river. Each rainbow smelt was given an acclimation period of $5 \mathrm{~min}$ and if a fish escaped from the refuge (e.g., jumping out of

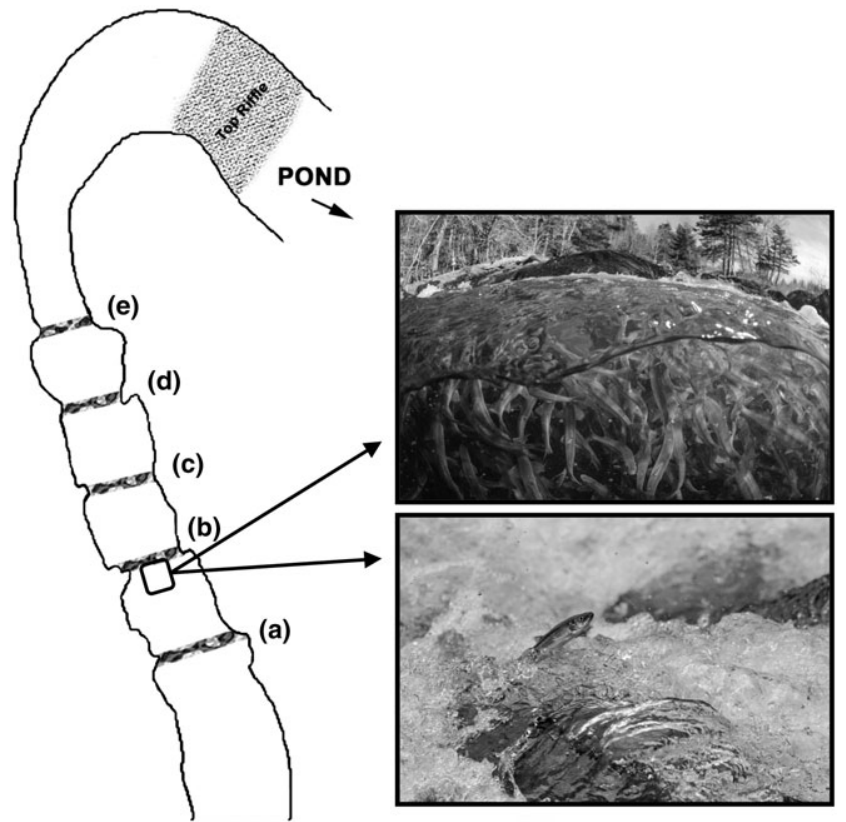

FIGURE 1 Schematic (not to scale) of the Pisquid River nature-like fishway. Rock weirs separate each pool (a-e). Passive integrated transponder tag antennas were located at the top riffle (full passage), below weir A (approach antenna), and at each weir except weir D. Drop heights between each pool range from 0.11-0.26 $\mathrm{m}$ with the largest drop height located at weir $B$. The inset photos show a large school of rainbow smelt below weir B (top) and a single rainbow smelt attempting to jump through the rapids at weir B (bottom; photos: Sean Landsman) 
(a)

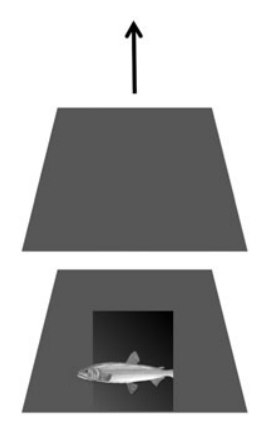

(b)



FIGURE 2 Diagram (not to scale) of the refuge chamber assembly (a) and the tanks (b) used to assess latency to emerge from a refuge chamber, activity, and predator response. The refuge chamber is located in the lower one third of the tank and each white line was spaced equidistant (b). Each refuge chamber consisted of two inverted pots (a). An outer pot acted as the closed door and was lifted after allowing the fish to acclimate for $5 \mathrm{~min}$. The inner pot contained an opening that the fish could swim through under its own volition (a)

the opening in the top of the refuge or wedging themselves underneath and out of the refuge) within this period, it was removed from the study. After the acclimation period, the refuge was opened (Figure 2a) and the fish was allowed to exit. Fish in the refuge chambers were given $600 \mathrm{~s}$ (i.e., $10 \mathrm{~min}$ ) to leave the chamber, and if they did not exit, the trial ended. If a fish did exit, an observer recorded the latency for the fish to leave the refuge (i.e., exploratory behaviour; Wilson \& Godin, 2009) and the fish was given an additional $600 \mathrm{~s}$ to move around the arena. The observer recorded the fish's activity (Wilson \& Godin, 2009) using a small hand-held counter to count the number of white lines within the tank that the fish crossed (Figure 2; Supporting Information). Predator avoidance behaviour (see Réale, Reader, Sol, McDougall, \& Dingemanse, 2007) was quantified at the end of each trial by using a small dip net passed twice above the tank (approximately $30-\mathrm{cm}$ height, $1 \mathrm{~s}$ per pass) to simulate movement by an avian predator. A positive response was defined as rapid, burst swimming in the tank, and the duration of the response was timed and recorded. The same procedures described in this section were also applied to a subsample of 50 (untagged) individuals captured above the fishway.

To minimize the potential effect of weather on the behaviour of rainbow smelt, trials were not conducted in sustained winds greater than $30 \mathrm{kmh}$ or during rain events. However, because of the need to conduct many trials and because each trial took at least $15 \mathrm{~min}$, trials were conducted in a variety of weather conditions. Observers positioned themselves behind the refuge side of the experimental arena so as not to influence fish behaviour or cast shadows across the tanks. Partial to full water changes were performed every 2-3 trials.

To test repeatability of behaviour (see Killen, Adriaenssens, Marras, Claireaux, \& Cooke, 2016), a subsample of 40 smelt (on two separate sampling days) was tested twice. Following the completion of the first test, each individual was placed in a holding bucket with fresh river water. To minimize disturbances triggered by the researchers and to keep temperatures within the buckets low, the fish were placed approximately $10 \mathrm{~m}$ away from the testing area and in a shaded location. Meanwhile, a new batch of rainbow smelt was tested and, following completion of their trials, the original group of rainbow smelt was tested a second time. Although not standardized, time between tests was approximately 25-30 min.

\section{4 | Objective 2-movement through fishway}

To determine movements of rainbow smelt through the fishway ( $n=276$ ), a small puncture was made with a needle sized for 12-mm passive integrated transponder (PIT) tags and a 23-mm half-duplex (HDX) PIT tag (either Biomark, model BIO23.HDX.03 V2 or Oregon RFID, HDX $23 \mathrm{~mm}+\mathrm{PIT}$ tag) was then manually inserted into the intraperitoneal cavity of each rainbow smelt. The tags weighed $0.6 \mathrm{~g}$ in air. A length-weight relationship using data from the same site but from a study conducted in 2014 indicated that the smallest fish from this study (125-mm male) had a tag-to-body mass ratio of $12.5 \%$. Brown, Cooke, Anderson, and McKinley (1999) found that a 12\% tag-to-body mass ratio did not significantly affect the swimming performance of rainbow trout (Oncorhynchus mykiss). After tagging, each test subject's total length was recorded to the nearest millimetre. Weights were not recorded to reduce handling times and air exposure. Each individual was also sexed by gently squeezing the abdomen to determine the presence of either eggs or milt. All tagged fish were released at a standardized location below the fishway.

Six antennas (7.5- to 10-m length) were connected to two multiantenna HDX readers, and the top riffle antenna was connected to a single antenna HDX reader (Oregon RFID; Portland, Oregon). All readers were synchronized (for additional details about antenna design and performance see Supporting Information). When a fish released downstream of the fishway was detected at an antenna within the structure, the readers logged its tag code as well as a date and time stamp. Data were downloaded 3-5 times per week. The fishway performance metrics of approach efficiency (the number of fish detected at the approach antenna out of the total number of rainbow smelt that were tagged), entrance efficiency (the number of fish passing the first weir out of the total number approaching the fishway), and passage efficiency (the number of fish passing the structure of the total that entered) were also calculated using the telemetry data (as per Bunt et al., 2012).

\section{5 | Statistical analysis}

Spearman's rank correlation analysis (with Bonferonni-adjusted $p$ values) was used to assess relationships among latency to emerge from the refuge, activity, and predator response. For latency to emerge from the refuge, fish that did not exit were assigned the full $600 \mathrm{~s}$ in the database and analysis of the remaining two metrics was confined only to fish that actually left the refuge. Preliminary analysis showed that the same behavioural metrics were significantly correlated and that the direction of correlation was also the same when separated by 
sex, thus we decided to pool data from both sexes. Data from all three behavioural metrics for those that emerged from the refuge were also entered into principal components analysis (PCA) and collapsed into a single principal component 1 (PC1) score to provide a composite boldness score (Bell, 2004; Wilson et al., 2010). Repeatability analyses were conducted using the intraclass correlation coefficient (ICC; Lessells \& Boag, 1987; Killen et al., 2016) using the "irr" package in R (Gamer, Lemon, Fellows, \& Singh, 2012). The ICC uses the variability components from a one-way analysis of variance to compare the among- and within-individual variance components. The proportion of variation attributed to among-individuals provides a measure of repeatability (Lessells \& Boag, 1987; Wolak, Fairbairn, \& Paulsen, 2012). Finally, separate nonparametric Wilcoxon rank-sum tests were used to assess behavioural differences between fish sampled below and above $(n=50)$ as well as between those that did $(n=142)$ and did not ( $n=135$ ) approach the fishway. Only fish captured below the fishway and within a temperature range of $8.2-9.4^{\circ} \mathrm{C}$ were included in analysis $(n=106)$ in order to achieve more even sample sizes. This temperature range corresponded to the mean daily temperatures for the 2 days (i.e., May 24 and 25) that smelt were sampled above the fishway.

Analysis of fishway passage data was confined to age- 2 individuals (male cut-off: $165 \mathrm{~mm}$; female cut-off: $175 \mathrm{~mm}$ ) because this age class constitutes over $60 \%$ of the migration in the Pisquid River (Torterotot, Bergeron, \& Clément, 2009) and due to concerns about unequal sample sizes among age-classes. Overall, the passage data were analysed using a four-step approach. First, preliminary analysis was conducted using permutational multivariate analysis of variance (PERMANOVA Primer-E; Clarke \& Gorley, 2006) to determine if any differences existed between groups of interest, which included fish that were successful or unsuccessful at passing the fishway as well as between sexes. The second step was to use homogeneity of dispersion (PERMDISP, Primer-E software) analysis to determine if there was significant variation between groups of interest. The third step applied PCA to visualize relationships among the independent variables and the groups of interest ("prcomp" function, R Studio Team, 2015). Only PCs of eigenvalues $>1.00$ were plotted (Kaiser, 1960). All independent variables were log transformed as well as normalized for PERMANOVA, PERMDISP, and PCA to reduce both redundancy within the dataset (Anderson, Gorley, \& Clarke, 2008) and the effects of outlier observations.

Lastly, logistic regression was used to examine the effects of our independent variables on the likelihood of passing the fishway (treated as a binary response; Faraway, 2006). Tag date was considered a nuisance factor and held as a random block effect (Bolker et al., 2009; Faraway, 2006), which required a generalized linear mixed model approach ("glmer" function within the Ime4 package; Bates, Maechler, Bolker, \& Walker, 2015). Distance moved through the fishway was analysed using a cumulative link mixed model (CLMM; Agresti, 2002; "clmm2" command within R's "ordinal" package; Christensen, 2015) where distance moved was treated as an ordinal response variable and tag date was held as a random block effect. For both analyses, model selection was accomplished by comparing the Akaike information criterion values adjusted for small sample sizes (AICc). A series of candidate models were created using a priori knowledge of factors and factor combinations that could affect the response variables. The change in $\mathrm{AIC}$ values (i.e., $\triangle \mathrm{AICC}$ ) between each successive model was used as the ranking criteria. The most supportive models were those with $\triangle \mathrm{AICC}$ values $\leq 2.00$ units from the top ranked model (Burnham \& Anderson, 2004). Chi-squared goodness of fit tests was used to assess model fit of both required a generalized linear mixed models and CLMMs. All tests used a significance level of $\alpha \leq .05$ unless otherwise stated.

\section{3 | RESULTS}

\section{1 | Behavioural distributions and correlations}

Sizes of rainbow smelt used in the behavioural assays ranged from 125 to $211 \mathrm{~mm}$ with a mean of $154.3 \pm 11.2 \mathrm{~mm}$ standard deviation (SD; both sexes pooled, includes PIT tagged fish). Latency to exit the refuge chamber varied for these fish, with some leaving immediately and others never leaving the chamber (range: 0-600 s, mean $331 \pm 252 \mathrm{~s}$ $S D$ ). Data indicated a bimodal distribution for latencies to exit the refuge, with $25 \%(69 / 276)$ leaving in less than $60 \mathrm{~s}$ and $41 \%(114 / 276)$ of all fish never exiting. For those that exited the refuge $(n=166)$, the range of activity included individuals that remained completely motionless for $600 \mathrm{~s}$ to those that crossed at least one line per $1 \mathrm{~s}$ (range: 0-678, mean $163 \pm 125$ lines SD). Predator response times were generally less variable with $58 \%(96 / 166)$ showing no response and, in total, $86 \%$ of individuals responding for $5 \mathrm{~s}$ or less $(143 / 166)$. PC1 boldness scores using all three metrics ranged from -3.5 (extreme bold) to 2.8 (extreme shy) with a mean score of $-0.1 \pm 1.3$. Fish sampled were broadly distributed across the range of boldness scores.

Latency to exit the refuge and activity showed a significant, negative correlation $\left(r_{\mathrm{s}}=-.27, p<.05\right.$; Figure 3$)$; fish taking less time to exit the refuge were subsequently more active in the tanks. A significant, positive correlation $\left(r_{\mathrm{s}}=.35, p<.05\right.$; Figure 3) was also observed between activity and predator response; fish that were more active also burst swam around the tanks for longer periods of time. Virtually no correlation existed between latency to emerge from the refuge and predator response $\left(r_{\mathrm{s}}=-.03\right.$; Figure 3$)$, though fish that took longer to respond to a simulated predator tended to take less time to emerge from the refuge chambers. Finally, latency to emerge from the refuge $(r=.60$; Table 1$)$ and activity $(r=.79$; Table 1) were repeatable within individuals, but predator response was not $(r<.01$; Table 1$)$

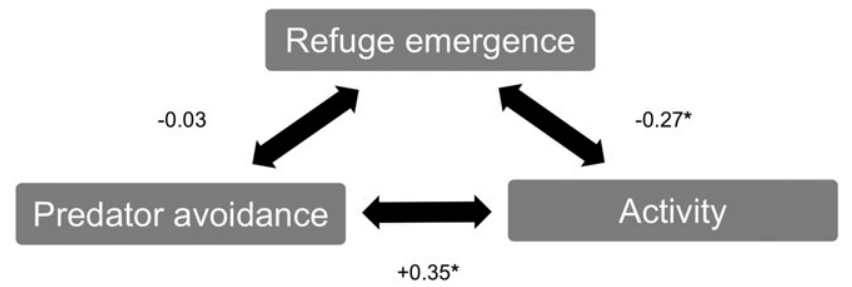

FIGURE 3 Behavioural syndrome showing correlations between two behaviours (i.e., refuge emergence/exploration and activity) in rainbow smelt. Numbers shown represent Spearman rho $\left(r_{\mathrm{s}}\right)$ correlations. Significant relationships denoted by an asterisk $\left({ }^{*}\right)$ 
TABLE 1 Outputs of ICC analysis on repeatability of behaviour within individuals. Bolded ICC values indicate significant repeatability tests at $p<.05$

\begin{tabular}{lccc} 
Behavioural test & ICC value $(r)$ & $\mathrm{Cl}$ & $\mathrm{N}$ \\
\hline Latency to emerge from the refuge & .60 & {$[0.26,0.79]$} & 40 \\
Activity & .79 & {$[0.38,0.93]$} & 15 \\
Predator response & $.00^{\mathrm{a}}$ & {$[-2.68,0.57]$} & 15 \\
\hline
\end{tabular}

Note. $\mathrm{Cl}=$ confidence interval; $\mathrm{ICC}=$ intraclass correlation coefficient.

a ICC value originally -.27 , but constrained to .00 (Baldwin, Murray, \& Shadish, 2005)

\subsection{Behavioural characteristics of successfully ascending fish}

The subsample of untagged rainbow smelt sourced from above the fishway ranged in size from 140 to $189 \mathrm{~mm}$ with a mean of $153.5 \pm 9.2 \mathrm{~mm}$ $S D$ (both sexes pooled). These individuals took significantly more time to exit the refuge chamber than fish sourced from below the fishway ( $W=1693, p<.001$; Figure 4). They were also significantly less active than rainbow smelt below the fishway ( $W=1056, p=.01$; Figure 4). Response to a simulated predator was not significantly different
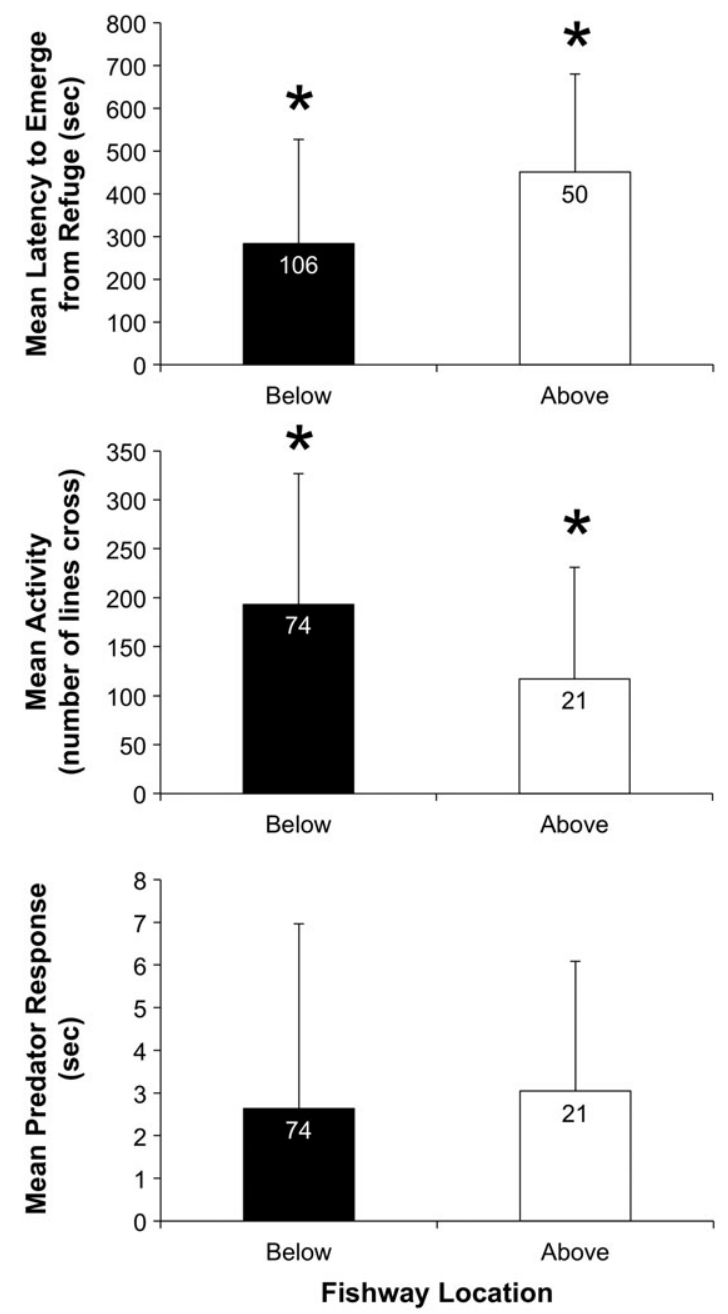

FIGURE 4 Mean latency to emerge from the refuge (top), mean activity (middle), and mean predator response (bottom) for rainbow smelt sampled below and above the nature-like fishway. Asterisks $\left({ }^{*}\right)$ represent significant differences between groups. Sample sizes are shown within each bar between rainbow smelt sampled above versus below the fishway $(W=652.5, p>$.05; Figure 4).

\section{3 | Fishway movements}

Of the 276 PIT tagged rainbow smelt, 51.4\% (142/276) approached the nature-like rock-ramp fishway, and of those $89.4 \%$ (127/142) entered the fishway. Fish that approached compared to those that were never detected were not significantly more active $(W=3895, p>.05)$ nor did they take more time to exit the refuge ( $W=10401, p>.05)$. However, in response to the simulated predator, fish that approached the fishway burst swam for a significantly longer time than fish that did not approach ( $W=4155, p<.05$ ). Of the rainbow smelt entering the fishway, less than half $(41.7 \% ; 53 / 127)$ successfully passed.

The attributes of each group of our predictor variables were not significantly different (PERMANOVA passage group, $F(1,138)=2.26$, $p>.05$; sexes $F(1,138)=0.49, p>.05)$. However, there was significantly more variability for fish that failed to pass relative to successfully passing fish (PERMDISP, $t=5.25, p<.05$ ) as well as for males compared to females ( $t=2.77, p<.05$ ).

PCA was conducted following PERMDISP to visualize relationships among variables and successful passage at the fishway. The highest amount of variation explained by a single PC was $26.5 \%$ (PC1; Table 2) and PCs $1-5$ cumulatively explained $91.6 \%$ of the variation (Table 2). There was little consistency among loading values for the predictor variables across all six PCs. However, PC1 was driven by water temperature and time to first detection, whereas PC2 was driven by discharge (Table 2). Relative to the first two PCs, successfully passing fish were associated with increased water temperature, lower discharge, and decreased time to first detection (Figure 5). Water temperature and discharge also loaded highly in PC5 and PC6, respectively (Table 2). In addition, time to first detection had the highest loading values for PC1 and PC4 (Table 2). Refuge emergence had not only the highest loading value for PC3 but also the lowest loading value for PC6 (Table 2).

The results of our logistic regression analysis supported the output of our PCAs. First, water temperature and discharge were common to each of the three most predictive models for males and for four of the five most predictive models for females. In each case, increased temperature and lower discharge were associated improved passage for both sexes. Water temperature was consistently a significant predictor whereas discharge, while present in the top ranked models, was nonsignificant where present (Table 3). Yet the odds ratio for discharge suggests a substantial decline in passage with a $1 \mathrm{~m}^{3} / \mathrm{s}$ increase where males and females were only $8.5-10.3 \%$ and $5.9-17.2 \%$ likely to pass the fishway, respectively. Length was also a significant factor in the most predictive model for female passage (Table 3). More specifically, the odds ratio for length indicated that with each 1-mm increase, females were $12 \%$ more likely to pass the fishway (Table 3). For females, the full model also had a $\triangle \mathrm{AIC}$ value $\leq 2.00$ and was the only model that contained latency to emerge from the refuge. However, this factor was non-significant. Latency to emerge from the refuge was not included in any of the most predictive models for male passage.

Distance moved in the fishway was affected by similar variables as successful passage. The most predictive model (and the only model 
TABLE 2 Principal components analysis output including factor loadings, eigenvalue, proportion of variance, and cumulative proportion of variance explained

\begin{tabular}{|c|c|c|c|c|c|c|}
\hline Variable & PC1 & PC2 & PC3 & PC4 & PC5 & PC6 \\
\hline Temperature & -0.52 & 0.16 & -0.12 & -0.39 & 0.71 & 0.18 \\
\hline Length & 0.32 & 0.37 & -0.59 & 0.53 & 0.27 & 0.27 \\
\hline Refuge emergence & -0.33 & -0.21 & -0.75 & -0.26 & -0.46 & 0.01 \\
\hline Passage attempts & 0.35 & -0.58 & -0.25 & -0.05 & 0.44 & -0.52 \\
\hline Time to first detection & 0.59 & -0.10 & -0.02 & -0.58 & -0.01 & 0.56 \\
\hline Proportion of variance & 0.27 & 0.22 & 0.16 & 0.14 & 0.13 & 0.08 \\
\hline Cumulative proportion of variance & 0.27 & 0.49 & 0.65 & 0.79 & 0.92 & 1.00 \\
\hline
\end{tabular}

Note. $\mathrm{PC}=$ principal component.
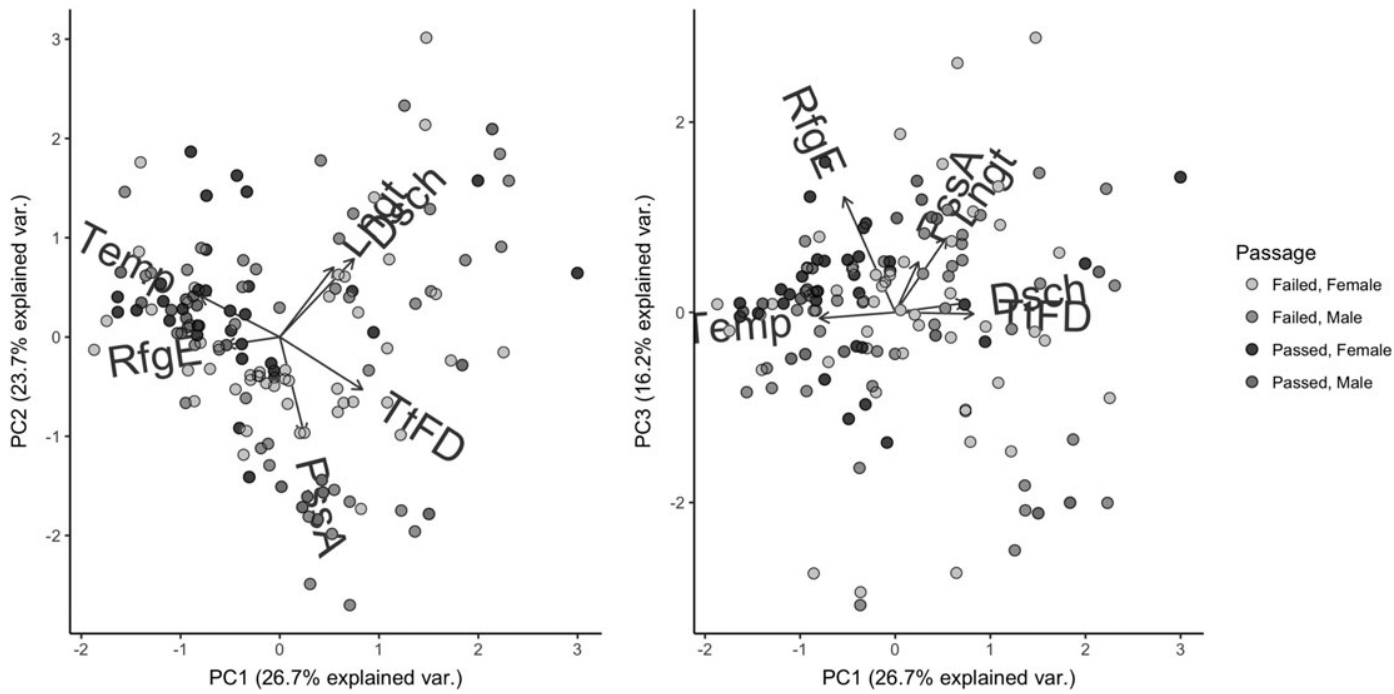

FIGURE 5 Principal component analysis biplots of principal components (PCs) 1, 2, and 3 (66.6\% cumulative variation) depicting the effects of refuge emergence (boldness), water temperature, discharge, length, passage attempts, and time to first detection on failure or success of male or female rainbow smelt to pass a nature-like fishway

TABLE 3 Results of logistic regression analysis for passage success of rainbow smelt at the Pisquid River nature-like fishway. Bolded values indicate significant effects.

\begin{tabular}{llccrr} 
Sex & \multicolumn{1}{c}{ Variable } & AICc & Coefficient & SE & OR [95\% CI] \\
\hline Male & Temperature & 71.4 & .37 & 0.17 & $1.44[1.01,2.06]$ \\
& Discharge & & -2.47 & .43 & $0.08[0.00,0.70]$ \\
Female & Temperature & 85.3 & .64 & 0.21 & $1.90[1.29,3.16]$ \\
& Length & & .11 & 0.06 & 1.71 \\
& Discharge & & -2.65 & $-.82[1.01,1.26]$ \\
& Passage attempts & & -.02 & 0.46 & $0.07[0.00,1.07]$ \\
& Time to first detection & & -.02 & 0.02 & $0.98[0.15,0.96]$ \\
& & & & $0.92,1.01]$
\end{tabular}

Note. The output presented is associated with the most predictive model for each sex. Bolded coefficient values indicate significant variables. AIC $=\mathrm{Akaike}$ information criterion; $\mathrm{Cl}=$ confidence interval; $\mathrm{OR}=$ odds ratio.

with a $\triangle \mathrm{AICc}$ value $\leq 2.00$ ) for males included the significant predictors of water temperature and number of passage attempts (Table 4). More specifically, increased water temperature and more passage attempts by males were associated with greater distance moved (Table 4). Discharge-and specifically lower discharge-was also present in the top model, though the effect was non-significant (Table 4). For females, four models had $\triangle \mathrm{AICC}$ values $<2.00$ and water temperature significantly affected distance moved in each of them. The most predictive model indicated that females moved shorter distances at increased discharges, but that higher water temperatures were associated with greater distance moved (Table 4).

\section{4 | DISCUSSION}

This study presents novel information relative to a behavioural syndrome in an anadromous fish species. Individual measures of behaviour were correlated and repeatable with the exception of the predator 
TABLE 4 Results of cumulative link mixed model analysis assessing distance moved in a nature-like fishway by male and female rainbow smelt. Bolded values indicate significant effects.

\begin{tabular}{|c|c|c|c|c|c|}
\hline Sex & Variable & $\mathrm{AlCc}$ & Estimate & $S E$ & OR $[95 \% \mathrm{Cl}]$ \\
\hline Males & $\begin{array}{l}\text { Temperature } \\
\text { Discharge } \\
\text { Passage attempts }\end{array}$ & 165.4 & $\begin{array}{r}.58 \\
-.23 \\
.69\end{array}$ & $\begin{array}{l}0.19 \\
0.59 \\
0.20\end{array}$ & $\begin{array}{l}1.79[1.24,2.56 \\
0.79[0.25,2.52 \\
1.99[1.33,2.97\end{array}$ \\
\hline
\end{tabular}

Note. The output presented is associated with the most predictive model for each sex. Bolded coefficient values indicate significant variables. AIC $=\mathrm{Akaike}$ information criterion; $\mathrm{Cl}$ = confidence interval; $\mathrm{OR}=$ odds ratio.

response metric. Repeatability suggests consistency of response across multiple contexts, though we acknowledge that the outcome may have been different if given a longer time between tests. Overall, our initial prediction that distinct behavioural types existed within a population of migratory rainbow smelt was confirmed. We predicted that bolder fish would be more likely to pass the fishway and move farther within the structure, but instead, boldness was not associated with successful passage or greater distances moved.

A boldness behavioural syndrome is associated with both higher activity and a greater willingness to explore novel environments (Wilson, 1998; Wilson \& Godin, 2009; Toms et al., 2010; Chapman et al., 2011). Although ideally the results of our behavioural assays would have yielded significant correlations across all three tests, a syndrome can be determined with two correlated behaviours (Sih et al., 2004; Conrad et al., 2011). In general, bolder rainbow smelt tended to take less time to emerge from the refuge and once in the novel environment were more active than those that took longer to leave the refuge. Greater activity was also related to increased predator response times. This finding is similar to increased activity associated with aggression toward an intruder (Dingemanse et al., 2007; Jones \& Godin, 2010) but differs from some studies that show more active fish spend less time fleeing a predator (Smith, Miner, Wiegmann, \& Newman, 2009). The composite boldness scores also indicated that the fish sampled represented a broad range of behavioural types including those that were extremely bold and those that were extremely shy.

Past studies have linked boldness in fishes with increased movement and greater migratory propensity. For example, increased dispersal distance was associated with bolder Trinidad killifish (Rivulus hartii; Fraser et al., 2001) and Gambusia spp. (Rehage \& Sih, 2004; Cote, Fogarty, Brodin, Weinersmith, \& Sih, 2011). In addition, bolder freshwater roach were more likely to migrate than shyer individuals (Chapman et al., 2011). However, the boldness metric (i.e., latency to emerge from the refuge) used in our logistic regression analysis was not included as a predictor in the top ranked model for either passage success or distance moved. It was, however, included in the full model for female passage success. Yet its odds ratio value of 1.00 implies that it had a neutral influence on passage success. Overall, we found little evidence to suggest that boldness significantly affected movement through the fishway indicating that other factors may have a stronger effect on passage.

Although water temperature was variable across the study period (Figure 6) it was consistently associated with successful passage and distance moved. Indeed, increasing water temperature is known to improve endurance (Brett, 1964; Videler \& Wardle, 1991) and overall swimming performance (Brett, 1971), although this is relative to a thermal optimum (i.e., performance does not increase indefinitely). Moreover, the associations we found between temperature and distance moved through the fishway are consistent with those of Haro, Castro-Santos, Noreika, and Odeh (2004) for blueback herring (Alosa aestivalis) and walleye (Sander vitreus) ascending experimental fishways. Greater length was also a significant predictor of passage success in females, despite confining the data set to only age-2 individuals. Larger size is often associated with higher absolute swim speeds and greater endurance (Beamish, 1978; Webb, Kostecki, \& Stevens, 1984; Videler \& Wardle, 1991), which may facilitate successful passage at fishways. Finally, reduced discharge was included in many of the most predictive models for both successful passage and distance moved through the fishway. Discharge steadily declined throughout the study period, and relatively low-discharge measurements were associated with higher water temperature (Figure 6). Although not necessarily a significant predictor in all models, the fact that it is present suggests that it plays a role on both response variables. The coefficients indicate that increased discharge-and thus higher water velocities within the fishway-greatly reduces passage success or the likelihood of reaching greater distances within the structure itself. This is likely a reflection of the rainbow smelt's relatively weak swimming abilities (Peake, 2008).

Greater passage attempt rates have been correlated with successful passage for some species such as alewife (Alosa pseudoharengus; Andrews, 2014). However, in this study, attempt rate was not a significant predictor of passage for fish of either sex but was significant for distance moved by males through the fishway. We posit that multiple passage attempts by rainbow smelt reflect, at least in part, searching behaviour as fish try to find the flow paths that reduce energy expenditure (Franklin, Haro, Castro-Santos, \& Noreika, 2012). Visual observations suggest that rainbow smelt have a strong affinity for zones of low flow, particularly along the extreme edges of the river. The use of low current speeds to reduce energy expenditure during migration has been hypothesized and demonstrated in other studies (e.g., Hinch \& Rand, 2000; Standen, Hinch, \& Rand, 2004 and see citations within).

Another potential factor that could drive movement of rainbow smelt through the Pisquid River nature-like fishway relates to the theory of ideal free distribution. Ideal free distribution states that available habitat becomes limited as population densities increase and that, in response, animals will seek out new, potentially lower quality habitats (Fretwell \& Lucas, 1970). The fishway in this study also represents spawning habitat for rainbow smelt (Clément et al., 2012; Landsman $\&$ van den Heuvel, in press). Given the observation that high densities of individuals often occupy the fishway during the migration, we posit 


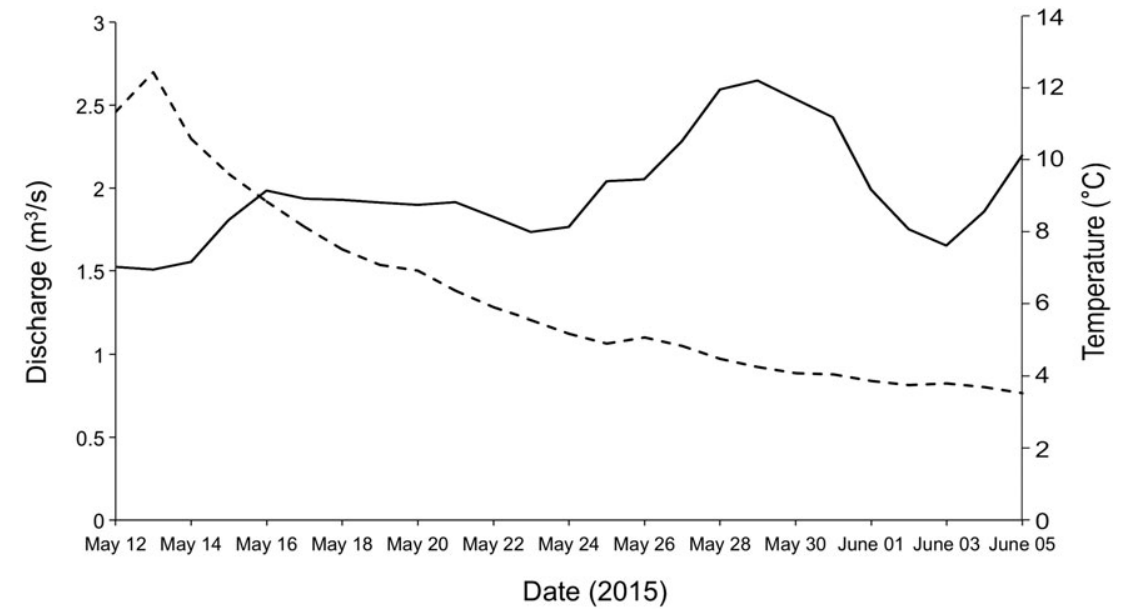

FIGURE 6 Mean daily discharge (dashed line) and water temperature (solid line) during the study period from the first day of detections on May 15, 2015 to the last day on June 8, 2015 that habitats within the fishway become saturated, forcing individuals to continue moving upstream. These movements may be attributed to competitive interactions between bold/dominant and shy/subordinate individuals (Dahlbom, Lagman, Lundstedt-Enkel, Sundström, \& Winberg, 2011).

If movement through the fishway were at least partly influenced by individual dominance, and if dominance in rainbow smelt was linked to boldness, then we would expect to see shyer individuals displaced by bolder fish and thus shyer rainbow smelt moving farther through the fishway. When fish sampled from above the fishway were subjected to our behavioural assays, the results indicated that smelt above the fishway took significantly longer to emerge from the refuge and were significantly less active, findings indicative of shyer individuals. However, the results of both our logistic regression and cumulative link models revealed no association with our boldness metric and either passage or distance moved. These discrepancies may be related to higher stress levels (e.g., exhaustion) that, after ascending the fishway, affect behaviour. Increased stress levels such as higher lactic acid concentrations have been observed in some species (e.g., alewife; Dominy, 1971) passing through fishways. Increases in the stress hormone cortisol were associated with lower boldness scores in juvenile mulloway (Argyosomus japonicas; Raoult, Brown, Zuberi, \& Williamson, 2012). Somatic energy reserves have been shown to vary considerably among Pacific salmon re-entering freshwater (Crossin, Hinch, Farrell, Higgs, \& Healey, 2004), and it is possible, though not expected, that energetic status could influence boldness in rainbow smelt. Future studies should determine whether a relationship exists between energetic status and consistency within boldness scores. Fish switching behavioural types has also been documented, whereby individuals that initially scored "bold" later switched to "shy" during testing in the second replicate (Raoult et al., 2012). Future studies investigating individual behaviour as it pertains to movements through fishways should attempt to account for changes in physiological status and exhaustion ideally by measuring energetic expenditure remotely from individual fish (see Hinch \& Bratty, 2000; Thiem et al., 2016).

Inclusive within the concept of an "ideal fishway" is the understanding that any phenotype of a given species should be able to pass a fishway (Castro-Santos, Cotel, \& Webb, 2009). In this study, the fact that behavioural type was not a predictor of a rainbow smelt's ability to successfully ascend the nature-like fishway suggests that the fishway was not selective against a particular behavioural type. Therefore, the structure partially meets the criteria of an ideal fishway. A natural extension of this study would be to apply a similar methodology at other fishway designs, specifically higher sloped technical fishways that have been found to select against certain phenotypes (e.g., Libby, 1981; Mallen-Cooper \& Stuart, 2007). In addition, this type of question may be best addressed in systems where there is no suitable spawning habitat downstream or within the fishway such that failure to pass equates to zero reproductive success (e.g., Pacific salmonids at some fishways). Moreover, there is a need to explore these issues across a range of fish species, ideally at a community level. Ultimately, nature-like fishways may represent the best-case scenario for the free passage of multiple behavioural types, but further study comparing multiple fishway designs is warranted.

Our study represents the first empirical test relating an anadromous fish's behavioural type with movement through a fishway. In general, however, the study of behaviour and its influence on fish passage is a research gap in need of further exploration (Castro-Santos et al., 2009). The factors that may influence successful passage are wide-ranging, but even properly designed fishways may not always lead to fish finding the entrance, or pass the fish that enter them, given the amount of behavioural variation that exists within populations (Williams et al., 2012; Cooke \& Hinch, 2013). It is thus imperative that subjects within fishway effectiveness studies represent a range of behavioural types. This study also suggests that nature-like fishways are a potentially useful fishway design for reducing phenotypic selection given our results that showed no selectivity against particular behavioural phenotypes.

\section{ACKNOWLEDGEMENTS}

We thank the following people from the University of Prince Edward Island for their assistance in the field: Hannah Gehrels, Kieran Moore, and Christina Pater. This research was funded by Ducks Unlimited Canada, the Prince Edward Island Wildlife Conservation Fund, the Natural Sciences and Engineering Research Council of Canada (NSERC), and Irving Oil. Landsman was supported by an NSERC Industrial Post Graduate Scholarship. Cooke and van den Heuvel were supported by the Canada Research Chairs Program. 


\section{REFERENCES}

Agresti, A. (2002). Categorical data analysis (2nd ed.). Hoboken, NJ: John Wiley \& Sons.

Anderson, M., Gorley, R. N., Clarke, R. K. (2008). Permanova+ for Primer: Guide to software and statistical methods.

Andrews, S. N. (2014). Fishways efficiency and passage behaviour of alewife in three fishways on Tantramar Marsh near Amherst, Nova Scotia. Masters Thesis. Acadia University.

Baldwin, S. A., Murray, D. M., \& Shadish, W. R. (2005). Empirically supported treatments or type I errors? Problems with the analysis of data from group-administered treatments. Journal of Consulting and Clinical Psychology, 73, 924-935.

Bates, D., Maechler, M., Bolker, B., \& Walker, S. (2015). Fitting linear mixedeffects models using Ime4. Journal of Statistical Software, 67, 1-48. https://doi.org/10.18637/jss.v067.i01

Beamish, F. W. H. (1978). Swimming capacity. In W. S. Hoar, \& D. J. Randall (Eds.), Fish physiology: Locomotion (pp. 101-189). New York, NY: Academic Press.

Bell, A. M. (2004). Behavioural differences between individuals and two populations of stickleback (Gasterosteus aculeatus): Behavioural syndromes. Journal of Evolutionary Biology, 18, 464-473.

Binder, T. R., Wilson, A. D. M., Wilson, S. M., Suski, C. D., Godin, J.-G. J., \& Cooke, S. J. (2016). Is there a pace-of-life syndrome linking boldness and metabolic capacity for locomotion in bluegill sunfish? Animal Behaviour, 121, 175-183.

Bolker, B. M., Brooks, M. E., Clark, C. J., Geange, S. W., Poulsen, J. R., Stevens, M. H., \& White, J. S. (2009). Generalized linear mixed models: A practical guide for ecology and evolution. Trends in Ecology \& Evolution, 24, 127-135.

Bretón, F., Baki, A. B. M., Link, O., Zhu, D. Z., \& Rajaratnam, N. (2013). Flow in nature-like fishway and its relation to fish behaviour. Canadian Journal of Civil Engineering, 40, 567-573.

Brett, J. R. (1964). The respiratory metabolism and swimming performance of young sockeye salmon. Journal of the Fisheries Board of Canada, 21 1183-1226.

Brett, J. R. (1971). Energetic responses of salmon to temperature. A study of some thermal relations in the physiology and freshwater ecology of sockeye salmon (Oncorhynchus nerka). American Zoologist, 11, 99-113.

Brown, R. S., Cooke, S. J., Anderson, W. G., \& McKinley, R. S. (1999). Evidence to challenge the " $2 \%$ rule" for biotelemetry. North American Journal of Fisheries Management, 19, 867-871.

Bunt, C. M., Castro-Santos, T., \& Haro, A. (2012). Performance of fish passage structures at upstream barriers to migration. River Research and Applications, 28, 457-478.

Burnham, K. P., \& Anderson, D. R. (2004). Multimodel inference understanding $\mathrm{AIC}$ and $\mathrm{BIC}$ in model selection. Sociological Methods \& Research, 33, 261-304.

Castro-Santos TR. 2002. Swimming performance of upstream migrant fishes: New methods, new perspectives (PhD Thesis). University of Massachusetts Amherst. pp. 186.

Castro-Santos, T. R., Cotel, A., \& Webb, P. W. (2009). Fishway evaluations for better bioengineering. In A. J. Haro, K. L. Smith, R. A. Rulifson, C. M. Moffit, R. J. Klauda, M. J. Dadswell, et al. (Eds.), Challenges for diadromous fishes in a dynamic global environment (pp. 557-575). Bethesda, MD: American Fisheries Society.

Chapman, B. B., Hulthén, K., Blomqvist, D. R., Hansson, L.-A., Nilsson, J.-Å., Brodersen, J., ... Brönmark, C. (2011). To boldly go: Individual differences in boldness influence migratory tendency: Boldness influences migratory tendency. Ecology Letters, 14, 871-876.

Chase, B. C. (2006). Rainbow smelt (Osmerus mordax) spawning habitat on the Gulf of Maine. Massachusetts Division of Marine Fisheries Technical Report TR-30. 180 pp.

Christensen, R. H. B. (2015). Ordinal-Regression models for ordinal data. R package version 2015.6-28. Retrieved from http://www.cran.r-project. org/package=ordinal/.
Clarke, K. R., \& Gorley, R. N. (2006). PRIMER v6: User manual/tutorial. Plymouth: PRIMER-E.

Clay, C. H. (1995). Design of fishways and other fish facilities. Boca Raton, FL: Lewis Publishers.

Clément, M., Torterotot, J.-B., \& Bergeron, N. E. (2012). Evaluation of rainbow smelt passage in a nature-like fishway. In C. H. Wood, C. Enterline, K. Mills, B. C. Chase, G. Verreault, J. Fischer, \& M. H. Ayer (Eds.), Fourth North American workshop on rainbow smelt: Extended abstract proceedings (Massachusetts Division of Marine Fisheries Technical Report TR-51) (pp. 54-60). Gloucester, Massachusetts: Massachusetts Division of Marine Fisheries

Conrad, J. L., Weinersmith, K. L., Brodin, T., Saltz, J. B., \& Sih, A. (2011). Behavioural syndromes in fishes: A review with implications for ecology and fisheries management. Journal of Fish Biology, 78, 395-435.

Cooke, S. J., \& Hinch, S. G. (2013). Improving the reliability of fishway attraction and passage efficiency estimates to inform fishway engineering, science, and practice. Ecological Engineering, 58, 123-132.

Cote, J., Fogarty, S., Brodin, T., Weinersmith, K., \& Sih, A. (2011). Personality-dependent dispersal in the invasive mosquitofish: Group composition matters. Proceedings of the Royal Society B: Biological Sciences, 278, 1670-1678. https://doi.org/10.1098/rspb.2010.1892

Crossin, G. T., Hinch, S. G., Farrell, A. P., Higgs, D. A., \& Healey, M. C. (2004). Somatic energy of sockeye salmon Oncorhynchus nerka at the onset of upriver migration: A comparison among ocean climate regimes. Fisheries Oceanography, 13, 345-349.

Dahlbom, S. J., Lagman, D., Lundstedt-Enkel, K., Sundström, L. F., \& Winberg, S. (2011). Boldness predicts social status in zebrafish (Danio rerio). PloS One, 6. e23565.

Dingemanse, N. J., Wright, J., Kazem, A. J., Thomas, D. K., Hickling, R., \& Dawnay, N. (2007). Behavioural syndromes differ predictably between 12 populations of three-spined stickleback. Journal of Animal Ecology, 76, 1128-1138.

Dominy, C. L. (1971). Changes in blood lactic acid concentrations in alewives (Alosa pseudoharengus) during passage through a pool and weir fishway. Journal of the Fisheries Research Board of Canada, 28, 1215-1217.

Faraway, J. J. (2006). Extending the linear model with R. Boca Raton, FL: Chapman \& Hall/CRC.

Franklin, A. E., Haro, A., Castro-Santos, T., \& Noreika, J. (2012). Evaluation of nature-like and technical fishways for the passage of alewives at two coastal streams in New England. Transactions of the American Fisheries Society, 141, 624-637. https://doi.org/10.1080/00028487.2012. 683469

Fraser, D. F., Gilliam, J. F., Daley, M. J., Le, A. N., \& Skalski, G. T. (2001). Explaining leptokurtic movement distributions: intrapopulation variation in boldness and exploration. The American Naturalist, 158, 124-135.

Fretwell, S. D., \& Lucas, H. L. J. (1970). On territorial behavior and other factors influencing habitat distribution in birds: I. Theoretical development. Ada Biotheoretica, 19, 16-36.

Gamer, M., Lemon, J., Fellows, I., Singh, P. (2012). IRR: Various coefficients of interrater reliability and agreement. $\mathrm{R}$ package version 0.84 . Retrieved from https://CRAN.R-project.org/package=irr

Harcourt, J. L., Sweetman, G., Johnstone, R. A., \& Manica, A. (2009). Personality counts: The effect of boldness on shoal choice in threespined sticklebacks. Animal Behaviour, 77, 1501-1505.

Haro, A., Odeh, M., Castro-Santos, T., \& Noreika, J. (1999). Effect of slope and headpond on passage of American shad and blueback herring through simple Denil and deepened Alaska steeppass fishways. North American Journal of Fisheries Management, 19, 51-58.

Haro, A., Castro-Santos, T., Noreika, J., \& Odeh, M. (2004). Swimming performance of upstream migrant fishes in open-channel flow: A new approach to predicting passage through velocity barriers. Canadian Journal of Fisheries and Aquatic Sciences, 61, 1590-1601.

Hinch, S. G., \& Bratty, J. (2000). Effects of swim speed and activity pattern on success of adult sockeye salmon migration through an area of 
difficult passage. Transactions of the American Fisheries Society, 129, 598-606.

Hinch, S. G., \& Rand, P. S. (2000). Optimal swimming speeds and forwardassisted propulsion: Energy-conserving behaviours of upriver-migrating adult salmon. Canadian Journal of Fisheries and Aquatic Sciences, 57, 2470-2478.

Hinch, S. G., Cooke, S. J., Healey, M. C., \& Farrell, A. P. (2005). Behavioural physiology of fish migrations: Salmon as a model approach. In K. A. Sloman, R. W. Wilson, \& S. Balshine (Eds.), Fish physiology (pp. 239-295). San Diego, California: Academic Press.

Hirsch, P. E., Thorlacius, M., Brodin, T., \& Burkhardt-Holm, P. (2016). An approach to incorporate individual personality in modeling fish dispersal across in-stream barriers. Ecology and Evolution, 7, 720-732.

Jones, K. A., \& Godin, J. G. (2010). Are fast explorers slow reactors? Linking personality type and anti-predator behaviour. Proceedings of the Royal Society of London B: Biological Sciences, 277, 625-632.

Kaiser, H. F. (1960). The application of electronic computers to factor analysis. Educational and Psychological Measurement, 20, 141-151.

Killen, S. S., Adriaenssens, B., Marras, S., Claireaux, G., \& Cooke, S. J. (2016). Context-dependency of trait repeatability and its relevance for management and conservation of fish populations. Conservation Physiology, 4. https://doi.org/10.1093/conphys/cow007

Kortet, R., Sirkka, I., Lai, Y.-T., Vainikka, A., \& Kekäläinen, J. (2015). Personality differences in two minnow populations that differ in their parasitism and predation risk. Frontiers in Ecology and Evolution, 3, 1-8.

Landsman, S. J., van den Heuvel, M. R. (in press). Fish passage requirements for rainbow smelt (Osmerus mordax) and gaspereau (alewife Alosa pseudoharengus and blueback herring $A$. aestivalis) at fishways and culverts: Current knowledge, research gaps, and recommendations. Department of Fisheries and Oceans Canada, Technical Report Series.

Larinier, M. (2002a). Pool fishways, pre-barages and natural bypass channels. Bulletin Français de la Pêche et de la Pisciculture, (364 supplement), 54-82.

Larinier, M. (2002b). Biological factors to be taken into account in the design of fishways, the concept of obstructions to upstream migration. Bulletin Français de la Pêche et de la Pisciculture, (364 supplement), 28-38.

Lessells, C. M., \& Boag, P. T. (1987). Unrepeatable repeatabilities: A common mistake. The Auk, 104, 116-121.

Libby, D. A. (1981). Difference in sex ratios of the anadromous alewife, Alosa pseudoharengus, between the top and bottom of a fishway at Damariscotta Lake, Maine. Fishery Bulletin, 79, 207-211.

Magnhagen, C., \& Borcherding, J. (2008). Risk-taking behaviour in foraging perch: Does predation pressure influence age-specific boldness? Animal Behaviour, 75, 509-517.

Mallen-Cooper, M., \& Stuart, I. G. (2007). Optimising Denil fishways for passage of small and large fishes. Fisheries Management and Ecology, 14, 61-71.

Maynard, G. A., Kinnison, M. T., \& Zydlewski, J. D. (2017). Size selection from fishways and potential evolutionary responses in a threatened Atlantic salmon population. River Research and Applications. https:// doi.org/10.1002/rra.3155

McLaughlin, R. L., Smyth, E. R. B., Castro-Santos, T., Jones, M. L., Koops, M. A., Pratt, T. C., \& Vélez-Espino, L.-A. (2013). Unintended consequences and trade-offs of fish passage. Fish and Fisheries, 14, 580-604.

Moring, J. (2005). Recent trends in anadromous fishes. In R. Buschbaum, J. Pederson, \& W. E. Robinson (Eds.), The decline of fisheries resources in New England: Evaluating the impact of overfishing, contamination, and habitat degradation (pp. 25-42). Cambridge, MA: MT Sea Grant College Program Massachusetts Institute of Technology.

Nilsson, A. (2015). Roach partial migration: Predation, personality and propensity. In The XV European Congress of Ichthyology, 7-11 September 2015. Porto, Portugal: Interdisciplinary Centre of Marine and Environmental Research.
Parasiewicz, P., Eberstaller, J., Weiss, S., \& Schmutz, S. (1998). Conceptual guidelines for nature-like bypass channels. In Fish Migration and Fish Bypasses (pp. 348-362). Oxford, UK: Fishing News Books.

Peake, S. J. (2008). Swimming performance and behaviour of fish species endemic to Newfoundland and Labrador: A literature review for the purpose of establishing design and water velocity criteria for fishways and culverts. Can. Manuscr. Rep. Fish. Aquat. Sci. 2843: $52 \mathrm{pp}$.

R Studio Team (2015). RStudio: Integrated development for R. Boston, MA: R Studio, Inc.

Raoult, V., Brown, C., Zuberi, A., \& Williamson, J. E. (2012). Blood cortisol concentrations predict boldness in juvenile mulloway (Argyosomus japonicus). Journal of Ethology, 30, 225-232.

Rasmussen, J. E., \& Belk, M. C. (2012). Dispersal behavior correlates with personality of a North American fish. Current Zoology, 58, 260-270.

Réale, D., Reader, S. M., Sol, D., McDougall, P. T., \& Dingemanse, N. J. (2007). Integrating animal temperament within ecology and evolution. Biological Reviews, 82, 291-318.

Rehage, J. S., \& Sih, A. (2004). Dispersal behavior, boldness, and the link to invasiveness: A comparison of four Gambusia species. Biological Invasions, 6, 379-391.

Scott, W. B., \& Scott, M. G. (1988). Atlantic fishes of Canada. Canadian Bulletin of Fisheries and Aquatic Sciences, 219, 150-154.

Sih, A., Bell, A., \& Johnson, J. C. (2004). Behavioral syndromes: An ecological and evolutionary overview. Trends in Ecology \& Evolution, 19, 372-378.

Smith, K. L., Miner, J. G., Wiegmann, D. D., \& Newman, S. P. (2009). Individual differences in exploratory and antipredator behaviour in juvenile smallmouth bass (Micropterus dolomieu). Behaviour, 146, 283-294.

Standen, E. M., Hinch, S. G., \& Rand, P. S. (2004). Influence of river speed on path selection by migrating adult sockeye salmon (Oncorhynchus nerka). Canadian Journal of Fisheries and Aquatic Sciences, 61, 905912.

Thiem, J. D., Dawson, J. W., Hatin, D., Danylchuk, A. J., Dumont, P., Gleiss, A. C., ... Cooke, S. J. (2016). Swimming activity and energetic costs of adult lake sturgeon during fishway passage. Journal of Experimental Biology, 219, 2534-2544.

Toms, C. N., Echevarria, D. J., \& Jouandot, D. J. (2010). A methodological review of personality-related studies in fish: Focus on the shy-bold axis of behavior. International Journal of Comparative Psychology, 23, 1-25.

Torterotot, J.-B., Bergeron, N. E., and Clément, M. (2009). Evaluation of passage efficiency of rainbow smelt in a nature-like fishway. Condensed Report: $21 \mathrm{pp}$.

Videler, J. J., \& Wardle, C. S. (1991). Fish swimming stride by stride: Speed limits and endurance. Reviews in Fish Biology and Fisheries, 1, 23-40.

Volpato, G. L., Barreto, R. E., Marcondes, A. L., Andrade Moreira, P. S., \& de Barros Ferreira, M. F. (2009). Fish ladders select fish traits on migration -Still a growing problem for natural fish populations. Marine and Freshwater Behaviour and Physiology, 42, 307-313.

Webb, P. W., Kostecki, P. T., \& Stevens, E. D. (1984). The effect of size and swimming speed on locomotor kinematics of rainbow trout. Journal of Experimental Biology, 109, 77-95.

Williams, J. G., Armstrong, G., Katopodis, C., Larinier, M., \& Travade, F. (2012). Thinking like a fish: a key ingredient for development of effective fish passage facilities at river obstructions. River Research and Applications, 28, 407-417.

Wilson, A. D. M., \& Godin, J.-G. J. (2009). Boldness and behavioral syndromes in the bluegill sunfish, Lepomis macrochirus. Behavioral Ecology, 20, 231-237.

Wilson, A. D. M., \& Godin, J.-G. J. (2010). Boldness and intermittent locomotion in the bluegill sunfish, Lepomis macrochirus. Behavioral Ecology, $21,57-62$ 
Wilson, A. D. M., Godin, J.-G. J., \& Ward, A. J. W. (2010). Boldness and reproductive fitness correlates in the eastern mosquitofish, Gambusia holbrooki. Ethology, 116, 96-104.

Wilson, D. S. (1998). Adaptive individual differences within single populations. Philosophical Transactions of the Royal Society of London B: Biological Sciences, 353, 199-205.

Wilson, D. S., Coleman, K., Clark, A. B., \& Biederman, L. (1993). Shy-bold continuum in pumpkinseed sunfish (Lepomis gibbosus): An ecological study of a psychological trait. Journal of Comparative Psychology, 107, 250-260.

Wolak, M. E., Fairbairn, D. J., \& Paulsen, Y. R. (2012). Guidelines for estimating repeatability: Guidelines for estimating repeatability. Methods in Ecology and Evolution, 3, 129-137.

\section{SUPPORTING INFORMATION}

Additional Supporting Information may be found online in the supporting information tab for this article.

How to cite this article: Landsman SJ, Wilson ADM, Cooke SJ, van den Heuvel MR. Fishway passage success for migratory rainbow smelt Osmerus mordax is not dictated by behavioural type. River Res Applic. 2017;33:1257-1267. https://doi.org/ 10.1002/rra.3176 